\title{
Effect of heat treatment prior to extraction on the yield and quality of red fruit (Pandanus conoideus) oil
}

\author{
1,* Sarungallo, Z.L., ${ }^{2,3}$ Hariyadi, P., ${ }^{2,3}$ Andarwulan, A. and ${ }^{2,3}$ Purnomo, E.H. \\ ${ }^{1}$ Department of Agricultural Technology, Papua University. Jl. Gunung Salju, Amban, Manokwari-98314, \\ West Papua, Indonesia \\ ${ }^{2}$ Department of Food Science and Technology, Faculty of Agricultural Engineering and Technology, Bogor \\ Agricultural University. IPB campus Darmaga, Bogor-16680, West Java, Indonesia \\ ${ }^{3}$ Southeast Asian Food and Agricultural Science and Technology (SEAFAST) Center, Bogor Agricultural \\ University. IPB Darmaga campus, Bogor-16680, West Java, Indonesia
}

\section{Article history:}

Received: 5 August 2019

Received in revised form: 27 October 2019

Accepted: 29 October 2019

Available Online: 4 January 2020

\section{Keywords:}

Steam pressure,

Temperature,

Free fatty acid,

Carotenoids,

Tocopherols

\section{DOI:}

https://doi.org/10.26656/fr.2017.4(3).281

\begin{abstract}
The quality of red fruit (Pandanus conoideus) oil (RFO) was strongly influenced by the processing and extraction method. The effect of heat treatment of red fruit using steam pressure at 100,110 and $120^{\circ} \mathrm{C}$ during 3-45 mins prior extraction using dry method, againts the oil yield, free fatty acid (FFA), total carotenoids and tocopherols of RFO were investigated, using experimental method. Heat treatment of the red fruit drupa (grains) using pressurized steam (autoclave) at the temperatures of 100,110 and $120^{\circ} \mathrm{C}$, with the pressure of 14.9 psi, for 3 to 45 mins before the oil is extracted by compression using Hydraulic Jack. Furthermore, RFO was analyzed for oil yield, FFA level, total content of carotenoids and tocopherols. The results showed that heating treatment prior extraction increased the oil yield, but decreased carotenoid and tocopherol content. Heating treatment also increased the FFA levels; but tend to decrease with the increasing of temperature and heating time. The minimum FFA level was obtained from heat treatment at $120^{\circ} \mathrm{C}$ for $20 \mathrm{mins}$, with the highest oil yield $(11.5 \pm 0.3 \%$ of total grains extracted), and the carotenoids and tocopherols content of $6148 \pm 65 \mathrm{ppm}$ and $1515 \pm 24 \mathrm{ppm}$, respectively, as well as the FFA level of $0.76 \pm 0.1 \%$, no significant difference $(\mathrm{P}<0.05)$ with the control $(0.71 \pm 0.2 \%)$. To further reduce the FFA content, it is recommended to study the effects of heat treatment of red fruit immediately after harvest.
\end{abstract}

\section{Introduction}

Red fruit oil (Pandanus conoideus) (RFO) is highly potential as a functional food because it contains several active components such as $\alpha$-carotene, $\beta$-carotene, $\beta$ cryptoxanthin and $\alpha$-tocopherol, as well as unsaturated fatty acids oleate, linoleate, linolenic and palmitoleate (Sarungallo et al., 2015a; Sarungallo et al., 2015b). These active components are particularly susceptible to changes during handling and extraction that will affect the final quality of RFO (Sarungallo et al., 2013). One of the important quality criteria of vegetable oil is the content of free fatty acids (FFA); which associated with undesirable rancid flavor (hydrolytic rancidity) and very easy to oxidize (Bhosle and Subramanian, 2005). The level of FFA from traditionally extracted RFO (the method of wet extraction) is reported to be very high, ranging from 6.16 to $21.96 \%$ (Pohan and Wardayani, 2006). Sarungallo et al. (2015b) also reported that the FFA content of 9 extracts of RFO extracted using a solvent (chloroform-methanol) varied from 4.3-9.2\%.

The high FFA content in RFO is thought to be due to a hydrolysis reaction catalyzed by endogenous lipase in red fruit. According to Ngando et al. (2006), FFA can be formed by enzymes (lipases) that catalyze the reaction of fat hydrolysis in the fruit after harvest in the presence of water. Sambanthamurthi et al. (1991) also reported that the FFA of palm oil is produced by the action of endogenous lipase triggered by fruit tissue injury during the harvesting process. Therefore, red fruit with a fat content of 11-30\% (Murtiningrum et al., 2012) are also highly susceptible to lipase activity. Inactivation of fruit endogenous lipases before oil extraction then may be suggested to decrease FFA level.

The optimum temperature for lipase activity in the plants is in the range of 20 to $38^{\circ} \mathrm{C}$ (Pahoja and Sethar, 2002), up to $50-55^{\circ} \mathrm{C}$ (Ngando et al., 2006; Matthaus, 2012). It is therefore hypothesized that the inactivation 
of lipase by heating the fruit can be used to control the level of FFA in the extracted oil. According to Anderson (2005) before the oil extraction, palm fruit was heated using high pressure to eliminate microorganisms, inactivate lipase which will produce FFA, and soften the fruit flesh. Lubis et al. (2012) reported that oil yield of red fruit was increased by heating using autoclave at a temperature of $120^{\circ} \mathrm{C}$ for $30-60$ mins, but the effect on FFA level, total carotenoid and tocopherol content were not reported. Sarungallo et al., (2014) also reported that oil extraction through dry method (compression) including steps of steaming caused decreasing of the FFA but increasing of RFO yield compared to wet method extraction. According to Kemper (2005) before the oil extraction, palm fruit was heated using high pressure to eliminate microorganisms, inactivate lipase which will produce FFA and soften the fruit flesh.

The objective of this research was to study the effect of heat treatment of red fruits using pressurized steam (autoclaves) in the temperature of 100,110 and $120^{\circ} \mathrm{C}$ for 3-45 mins prior to extraction on the yield, the FFA levels, total carotenoids as well as tocopherols total of red fruit oil obtained by dry method of oil extraction.

\section{Materials and methods}

\subsection{Materials}

The main raw material in this study was a clone of red fruits, with the local name of Monsor, obtained from the Experimental Farm, The University of Papua (UNIPA), Manokwari, West Papua Province, Indonesia. Red fruits were harvested at optimum maturity, characterized by the leaf sheath of the fruit has opened and $50 \%$ of the leaf has dried out and the fruit already developed full grain (pithy) with dark red color. The harvested red fruit was left at room temperature for 2 days to soften the flesh of fruit as well as facilitate the separation of grain from the pith easily.

Chemicals used for the analysis with analytical grade levels consist of phosphate buffer, p-nitrophenilbutyrate and p-nitrophenol from Sigma-Aldrich, Inc. (MO, USA), sodium hydroxyde, phenolphthalein, butylated hydroxyl toluene (BHT), hexane, toluene, ethanol, 2,2 bipyridine and $\mathrm{FeCl}_{3} \cdot 6 \mathrm{H}_{2} \mathrm{O}$ were obtained from Merck, Darmstadt, Germany. While the $\alpha$-tocopherol standard was purchased from Wako Pure Industries, Ltd. Tokyo, Japan.

\subsection{Heat treatment of red fruit grains}

Before extraction, the grains (drupa) of red fruit were separated from the pith of the fruits (pedicel) using a knife. The Red fruit grains $( \pm 300 \mathrm{~g})$ are heated using an autoclave (ALL-American model 50x25 Quart
Electric sterilizer, USA), to reach a temperature of $120^{\circ}$ $\mathrm{C}$ (pressure of $14.9 \mathrm{psi}$ ), and then maintained for 3 to 20 mins according to the treatment as shown at Table 1. Heating is discontinued by turning off its heat source and opening the valve of autoclave, then the red fruit grains are removed from the autoclaves, and ready for extraction. Sample of red fruit grains without heating was used as controls.

Table 1. The treatment of temperature and heating time of red fruit grains in the autoclave

\begin{tabular}{lccccccc}
\hline Set temperature of & \multicolumn{7}{c}{ Heating time (mins) } \\
\hline 100 & 0 & 5 & 15 & 25 & 35 & 45 & \\
110 & 0 & 5 & 10 & 15 & 20 & 25 & 30 \\
120 & 0 & 3 & 6 & 9 & 12 & 15 & 20 \\
\hline
\end{tabular}

\subsection{Red fruit oil (RFO) extraction}

RFO extraction was done by using a dry extraction method. Grains of red fruit that has been heated using steam pressure (autoclave) were then compressed using a hydraulic jack ( 5 ton, Prohex- Germany). The pressing process took about 5 mins to produce a crude oil. The crude oil was then centrifuged ( $3000 \mathrm{rpm}, 15 \mathrm{mins}$ ) to obtain RFO, packaged in dark bottles and ready to be analyzed.

RFO analysis conducted on the yield of oil, FFA content, total carotenoids and tocopherols, as compared with the RFO extracted without heating (fresh grains of red fruit directly compressed with a hydraulic press and then centrifuged at $3000 \mathrm{ppm}$ for $15 \mathrm{mins}$ ). The experimental design used in this step was completely randomized design with 3 replications.

\subsection{Lipase analysis}

Lipase activity was observed in the fresh fruit either without heating and in heating condition by using autoclave at $100^{\circ} \mathrm{C}$ for 5 mins and $120^{\circ} \mathrm{C}$ for $20 \mathrm{mins}$, which was determined by using the method of Lopes et al. (2011) with slight modifications. A total of $\pm 0.5 \mathrm{~g}$ grains of red fruit were crushed in $5 \mathrm{~mL} 0.05 \mathrm{M}$ phosphate buffer $\mathrm{pH} 7$ and the filtrate was centrifuged (5000 ppm, 5 mins). The filtrate obtained was diluted (100 times) with $0.05 \mathrm{M}$ phosphate buffer $\mathrm{pH} 7$. A total of $0.45 \mathrm{~mL}$ of sample solution was added with $0.54 \mathrm{~mL}$ of $0.05 \mathrm{M}$ phosphate buffer $\mathrm{pH} 7$ and $0.01 \mathrm{~mL}$ of $0.2 \mathrm{M} \mathrm{p}$ -nitrophenil butyric (solvent dimethyl sulfoxide). The solution was then incubated at $35^{\circ} \mathrm{C}$ for 10 mins and the absorbance was measured at a wavelength of $410 \mathrm{~nm}$ using spectrophotometer (Shimadzu UV-2450, Kyoto, Jepang). Lipase activity was calculated based on a standard curve of p-nitrophenol (PNP), using the following equation: 
Lipase activity $\left(\frac{\mathrm{U}}{\mathrm{mg}}\right)=\frac{\text { Absorbance }-b}{a} \times \frac{1}{\text { time incubation (min) }} \times \frac{1}{\operatorname{MW~PNP~(139.1)}} \times$ Dilution

Where MW PNP is the molecular weight of 4Nitrophenol $(139.1 \mathrm{~g} / \mathrm{mol}) ; a$ is the intercept of standard curve; and $b$ is the gradient of standard curve.

\subsection{Analysis of yield and quality of red fruit oil (RFO)}

The yield of RFO extraction was calculated as a percentage of the oil to total mass of grains sample. The free fatty acid (FFA) content was analyzed by titration methods (AOCS, 2017). Total carotenoid content was determined using the method of Knockaert et al. (2012) with slight modifications. A total of $2 \mathrm{mg}$ of each sample was dissolved in $0.1 \%$ of butylated hydroxyl toluene (BHT) solution in hexane. The absorbance of the sample solution was measured spectrophotometrically (Shimadzu UV-2450, Kyoto, Japan) at a wavelength of $470 \mathrm{~nm}$ with $0.1 \%$ BHT in hexane as a blank. Total carotenoids were calculated using the following equation:

$$
\text { Carotenoid concentration }(\mathrm{ppm})=\frac{\left.\mathrm{AxV}(\mathrm{mL}) \times 10^{4}\right)}{\mathrm{E}_{1 \mathrm{~cm}}^{196} \times \text { sample weight }(\mathrm{g})}
$$

Where $\mathrm{A}$ is the absorbance value, $\mathrm{V}$ is the total volume of sample solutions, $\mathrm{E}_{\mathrm{lcm}}^{196}$ is the extinction coefficient = 2,560 for $\beta$-carotene in hexane.

Total tocopherol was determined using the method of Wong et al. (1988). Approximately $0.01 \mathrm{~g}$ of oil was filled in the volumetric flask $(10 \mathrm{~mL})$, then added with 5 $\mathrm{mL}$ of toluene, $3.5 \mathrm{~mL}$ of 2,2 bipyridine $(0.07 \%$ weight per volume $(\mathrm{w} / \mathrm{v})$ in $95 \%$ ethanol) and $0.5 \mathrm{~mL}$ $\mathrm{FeCl}_{3} \cdot 6 \mathrm{H}_{2} \mathrm{O}(0.2 \% \mathrm{w} / \mathrm{v}$ in $95 \%$ ethanol $)$. The solution was added with $95 \%$ ethanol to $10 \mathrm{~mL}$ and the absorbance was measured at a wavelength of $520 \mathrm{~nm}$ using spectrophotometer (Shimadzu UV-2450, Kyoto, Jepang). A blank was made the same way without the sample. The total tocopherol concentration was calculated based on a standard curve of $\alpha$-tocopherol (100-1,500 ppm in toluene).

\subsection{Data analysis}

Data were shown as tables of mean values and standard deviation. The discussion was based on oneway analysis of variance (ANOVA) followed by Duncan Multiple Region Test (DMRT) with the level of significance at $\mathrm{P}<0.05$. All statistical analyses were performed using the Statistical Analysis Software (SAS) 9.1.3 program. Average data of triplicate samples were used in the analysis.

\section{Results and discussion}

\subsection{Effect of heat treatment}

Data in Table 2 summarizes the effect of heat treatment on the oil yield and some aspects of RFO quality. Specifically, Figure 1 (data from Table 2) illustrates that heating of red fruit seeds before extraction can significantly increase oil yield. Figure 2 shows that the yield of oil extraction increases as temperature and heating time increases. Increased RFO yield during the heating process using autoclave can be attributed to the heating effect of fruit tissue, tenderizing fleshy fruit, coagulating protein and damaging the cell wall, thus releasing oil droplets more easily. In addition, heat can also decrease the viscosity of fat in the fruit flesh so that more oil was extracted by using hydraulic compression (Kemper, 2005).

Figure 1 shows that RFO yields increase with the increasing of heating time. The higher the heating temperature the higher the yield of RFO. The maximum oil yield $(11.5 \pm 0.3 \%), 57.5 \%$ increased as compared to that of the control $(7.3 \pm 0.8 \%)$, achieved in this experiment was obtained from sample heated at $120^{\circ} \mathrm{C}$ for 20 mins. A similar phenomenon has also been reported in RFO (Lubis et al., 2012) and palm oil (Fauzi and Sarmidi, 2010a).

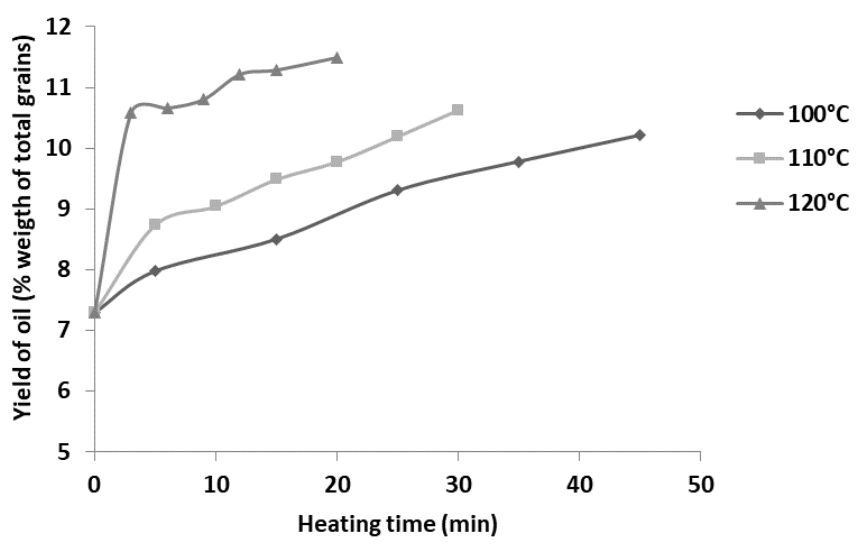

Figure 1. The yield of red fruit oil as affected by heating temperature $\left(100^{\circ} \mathrm{C}, 110^{\circ} \mathrm{C}\right.$, and $\left.120^{\circ} \mathrm{C}\right)$ for $3-45$ mins.

Our data also show that FFA content of RFO is affected by the temperature and time of heating significantly $(\mathrm{P}<0.05$; Table 2$)$. The FFA content of the oil control (without heat treatment) is the lowest $(7.06 \%)$ and will increase with the heating treatment. However, at the higher temperatures, the increasing level of FFA are lower. Heating at $100^{\circ} \mathrm{C}$ for $5 \mathrm{mins}$, for example, will increase FFA level to $2.38 \pm 1.4 \%$, three times higher than controls. Where heating the red fruit grains to $110^{\circ} \mathrm{C}$ for 5 mins increases the FFA level to $1.40 \pm 1.0 \%$ and heating at $120^{\circ} \mathrm{C}$ for 3 mins will increase the FFA level to $1.31 \pm 0.8 \%$. For all the heating temperature treatments, the FFA level will tend to decrease as the heating time increases as can be seen in Figure 2.

Figure 2 indicates that the heating treatment of the red fruit grains caused a complex phenomenon. With 
Table 2. The yield, free fatty acids (FFA), total carotenoids and total tocopherols content of red fruit oil (RFO) during heating process

\begin{tabular}{|c|c|c|c|c|c|}
\hline \multicolumn{2}{|c|}{ Heating process (autoclave) } & \multirow{2}{*}{$\begin{array}{c}\text { Yield oil } \\
(\%, \text { total grains })\end{array}$} & \multirow{2}{*}{ Free fatty acids $(\%)$} & \multirow{2}{*}{$\begin{array}{l}\text { Total carotenoid } \\
\text { (ppm) }\end{array}$} & \multirow{2}{*}{$\begin{array}{l}\text { Total tocopherol } \\
\text { (ppm) }\end{array}$} \\
\hline Temperature $\left({ }^{\circ} \mathrm{C}\right)$ & Time $^{* *}(\min )$ & & & & \\
\hline Control $^{* * *}$ & 0 & $7.3 \pm 0.8^{\mathrm{i}}$ & $0.71 \pm 0.2^{\mathrm{j}}$ & $7778 \pm 751^{\mathrm{a}}$ & $1667 \pm 105^{\mathrm{a}}$ \\
\hline \multirow[t]{5}{*}{100} & 5 & $8.0 \pm 0.2^{\text {ih }}$ & $2.38 \pm 1.4^{\mathrm{a}}$ & $7530 \pm 8^{\mathrm{ab}}$ & $1593 \pm 12^{b}$ \\
\hline & 15 & $8.5 \pm 0.5^{\mathrm{gh}}$ & $2.04 \pm 0.5^{\mathrm{b}}$ & $7215 \pm 219^{b c d}$ & $1568 \pm 21^{\mathrm{bcd}}$ \\
\hline & 25 & $9.3 \pm 0.3^{\mathrm{efg}}$ & $1.66 \pm 0.3^{\mathrm{c}}$ & $6990 \pm 281^{\mathrm{ed}}$ & $1557 \pm 33^{\text {bcde }}$ \\
\hline & 35 & $9.8 \pm 0.3^{\text {cdef }}$ & $1.36 \pm 0.2^{\mathrm{d}}$ & $6652 \pm 219^{\text {efg }}$ & $1534 \pm 30^{\text {def }}$ \\
\hline & 45 & $10.2 \pm 0.4^{\text {bcde }}$ & $1.14 \pm 0.5^{\mathrm{fg}}$ & $6375 \pm 119^{\mathrm{fgh}}$ & $1505 \pm 26^{\mathrm{f}}$ \\
\hline \multirow[t]{6}{*}{110} & 5 & $8.7 \pm 0.2^{\text {fgh }}$ & $1.40 \pm 1.0^{\mathrm{d}}$ & $7414 \pm 176^{\mathrm{bc}}$ & $1596 \pm 3^{\mathrm{b}}$ \\
\hline & 10 & $9.0 \pm 0.1^{\mathrm{efgh}}$ & $1.22 \pm 0.4^{\mathrm{ef}}$ & $7167 \pm 61^{\mathrm{cd}}$ & $1584 \pm 13^{\mathrm{bc}}$ \\
\hline & 15 & $9.5 \pm 0.0^{\text {defgh }}$ & $1.12 \pm 0.2^{\mathrm{g}}$ & $6975 \pm 8^{\text {ed }}$ & $1558 \pm 5^{\text {bcde }}$ \\
\hline & 20 & $9.8 \pm 0.1^{\text {cdef }}$ & $1.07 \pm 0.4^{\mathrm{gh}}$ & $6585 \pm 149^{\mathrm{fg}}$ & $1535 \pm 10^{\text {def }}$ \\
\hline & 25 & $10.2 \pm 0.1^{\text {bcde }}$ & $0.97 \pm 0.0^{\mathrm{hi}}$ & $63424 \pm 69^{\text {gh }}$ & $1522 \pm 16^{\mathrm{ef}}$ \\
\hline & 30 & $10.6 \pm 0.4^{\mathrm{abcd}}$ & $0.91 \pm 0.1^{\mathrm{i}}$ & $6133 \pm 73^{\mathrm{h}}$ & $1504 \pm 10^{\mathrm{f}}$ \\
\hline \multirow[t]{6}{*}{120} & 3 & $10.6 \pm 0.1^{\mathrm{abcd}}$ & $1.31 \pm 0.8^{\mathrm{de}}$ & $7372 \pm 109^{\mathrm{bc}}$ & $1589 \pm 16^{\mathrm{b}}$ \\
\hline & 6 & $10.7 \pm 0.6^{\mathrm{abcd}}$ & $1.17 \pm 0.2^{\mathrm{fg}}$ & $7185 \pm 121^{\mathrm{cd}}$ & $1579 \pm 10^{\mathrm{bcd}}$ \\
\hline & 9 & $10.8 \pm 0.6^{\mathrm{abc}}$ & $1.09 \pm 1.1^{\mathrm{g}}$ & $6991 \pm 42^{\mathrm{ed}}$ & $1570 \pm 12^{\mathrm{bcd}}$ \\
\hline & 12 & $11.2 \pm 1.1^{\mathrm{ab}}$ & $0.97 \pm 0.1^{\text {hi }}$ & $6772 \pm 120^{\mathrm{ef}}$ & $1558 \pm 17^{\text {bcde }}$ \\
\hline & 15 & $11.3 \pm 0.8^{\mathrm{ab}}$ & $0.88 \pm 0.5^{\mathrm{i}}$ & $6467 \pm 51^{\mathrm{fgh}}$ & $1540 \pm 31^{\text {cdef }}$ \\
\hline & 20 & $11.5 \pm 0.3^{\mathrm{a}}$ & $0.76 \pm 0.1^{j}$ & $6148 \pm 65^{\mathrm{h}}$ & $1515 \pm 24^{\mathrm{ef}}$ \\
\hline
\end{tabular}

Values are expressed as mean $\pm \mathrm{SD}(\mathrm{n}=3)$. Different superscript letter within a column indicates significant difference $(\mathrm{P}<0.05)$. **Heating time (maintained) in the autoclave. ***Control is a sample of grains of red fruit with no heat treatment prior to extraction. The grains of red fruits was directly pressed hydraulically to obtained oil then centrifuged at 5000 ppm for $20 \mathrm{mins}$.

respect to lipase activity, heating may potentially cause three main effects, namely to (i) deactivate the lipase activity, (ii) increase the reaction rate and (iii) damage the tissue causing decompartmentation to facilitate more contact between enzyme (lipase) and substrate (oil). This may explain that in the early stages of heating (during 3 5 mins of heating) the first effect (lipase inactivation) is still incomplete (not totally inactivated). Therefore, the second and third effects (increasing the reaction rate and the decompartmentation) are more dominant effects, so that the overall effect is increase in FFA content.

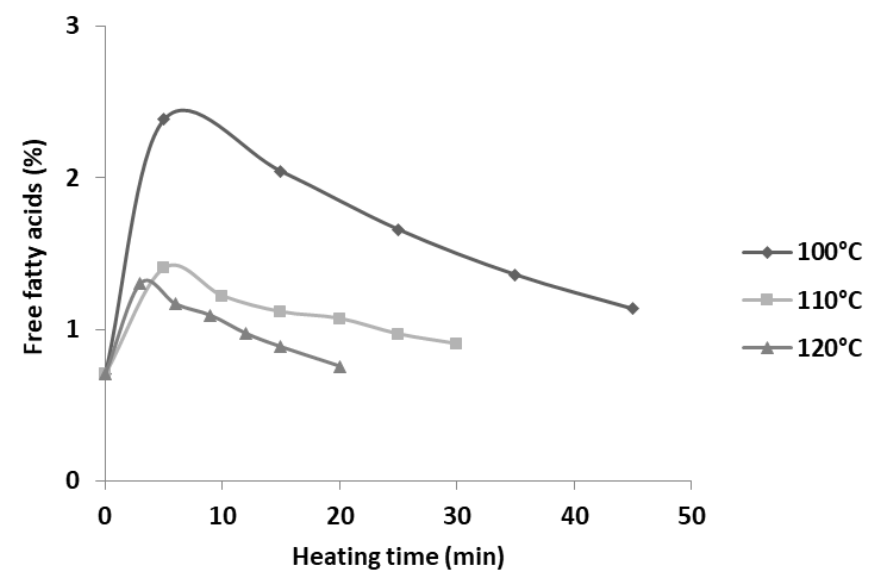

Figure 2. The changes in the levels of free fatty acids of red fruit oil as affected by heating temperature $\left(100^{\circ} \mathrm{C}, 110^{\circ} \mathrm{C}\right.$, and $120^{\circ} \mathrm{C}$ ) for $3-45$ mins.
These phenomena may be explained as follows. Heating of red fruit grains at $100^{\circ} \mathrm{C}$ for 5 mins (Figure 2) increases the FFA content as the result of oil hydrolysis by lipase, but a heating time of 15 to 45 mins will eventually reduce FFA level. This indicates that the heating (autoclave) at $100^{\circ} \mathrm{C}$ for $5 \mathrm{mins}$ is not enough to completely inactivate the red fruit lipase. This is supported by the results of the analysis of red fruit lipase activity (Table 3). Azeman et al., (2015) also reported studies on the influence of heating temperatures (at a range of 40 to $90^{\circ} \mathrm{C}$ ) on lipase (Thermomyces lanuginose) activity with spectrophotometer; where maximum absorptivity is seen at the reaction temperature of $70^{\circ} \mathrm{C}$. However, the absorptivity of the lipase decreases at a temperature higher than $70^{\circ} \mathrm{C}$ because the deactivation of the lipase occurs at $80^{\circ} \mathrm{C}$. But the activity of lipase at 80 and $90^{\circ} \mathrm{C}$ is still detected.

The control sample (red fruit after harvest was stored at room temperature for 2 days) had the highest lipase activity of $27.05 \mathrm{U} / \mathrm{mg}$ (Table 3 ), but the resulting oil had the lowest FFA content $(0.71 \pm 0.2 \%)$. This relatively low of FFA content is due to the low rate of reaction and less decompartmentation preventing the active enzyme from reacting with the substrate (oil). Once the fruits heated (for example up to $100^{\circ} \mathrm{C}$ for 5 mins), it causes fruit softening and cell damage that facilitates further 
reactions. The residual lipase (with the activity of $6.43 \pm 0.96 \mathrm{U} / \mathrm{mg}$ ), will still active to catalyze oil hydrolysis reaction, at which the possibility to form enzyme-substrate complex will increase due to decompartmentation; and the reaction rate will be accelerated due to increasing temperature, resulting in more FFA level of $2.38 \pm 1.4 \%$.

Table 3. Lipase activity of red fruit during heating treatment

\begin{tabular}{ccc}
\hline $\begin{array}{c}\text { Temperature heating } \\
\text { treatment of red fruit grains }\end{array}$ & $\begin{array}{c}\text { Time of } \\
\text { heating } \\
(\mathrm{min})\end{array}$ & $\begin{array}{c}\text { Lipase activity } \\
\text { (U/mg grain) }\end{array}$ \\
\hline Control (without heating) & 0 & $27.05 \pm 2.3$ \\
Heating (Autoclave) at $100^{\circ} \mathrm{C}$ & 5 & $6.43 \pm 0.96$ \\
Heating (Autoclave) at $120^{\circ} \mathrm{C}$ & 20 & $\mathrm{ND}^{* *}$ \\
\hline
\end{tabular}

Values are expressed as mean $\pm \mathrm{SD}(\mathrm{n}=3)$. ${ }^{* * \mathrm{ND}}=$ not detection

Increasing the heating temperature to $110^{\circ} \mathrm{C}$ and $120^{\circ} \mathrm{C}$ can reduce the FFA level of RFO, which decrease with the increasing of heating duration (Table 2). This is possible because the temperature rise during the heating treatment causes the denaturation of proteins that can soften the cell wall of the fruit, thus speeding up the release of oil and interacting with the lipase, subsequent hydrolysis reaction resulting in FFA. Then, the lipase hydrolysis reaction by the lipase (in red fruit) will continue during the oil extraction process, especially in the stages of fruit pressing and oil centrifugation (the duration of the process is about 15-20 mins) so the FFA level of the oil increases. Furthermore, with increased heating time (15-45 mins) will decrease FFA level. This decrease is possible because, with long duration of heating at high temperature, the lipase will be denatured to become inactive. This is reinforced by the data in Table 3 that heating at $120^{\circ} \mathrm{C}$ for 20 mins can deactivate lipase in red fruit. You and Bahrain (2006) also explain that the enzyme is a protein, which can be denatured at high temperatures, in which the secondary structure of proteins damaged. Secondary structural damage causes the three-dimensional structure of the protein to change, thus disrupting the function of lipase proteins in the hydrolyzing of fat.

Figure 2 also shows that the pattern of increase and decrease in FFA level of oil during heating in the temperature range of $0-100^{\circ} \mathrm{C}, 0-110^{\circ} \mathrm{C}$ and $0-120^{\circ} \mathrm{C}$ is relatively the same but decreases with the increasing of temperature. This indicates that in the heating process using an autoclave at $110^{\circ} \mathrm{C}$ and $120^{\circ} \mathrm{C}$, the initial warming will activate lipase that hydrolyzes fat resulting in FFA, but along with rising temperature and heating time, the enzyme is inactivated so that hydrolysis reaction is inhibited and FFA level decreases. It is therefore suspected that the heating conditions, heat penetration into the red fruit tissue for the inactivation of lipases are relatively similar.

The maximum heat penetration for lipase inactivation was achieved at $120^{\circ} \mathrm{C}$ for 20 mins, where the oil FFA content was not significantly different ( $\mathrm{P}$ $<0.05$ ) with oil extracted without heating. Li et al. (2012) also reported that FFA levels of extracted palm oil without heating was $24.3 \%$, but heating (sterilization) it at $100^{\circ} \mathrm{C}$ for $30 \mathrm{mins}$ would decrease lipase activity so that FFA levels reached $2.7 \%$. High levels of FFA of RFO (from Monsor clones) can be caused by lipase activity in the red fruit pulp before heating and produce FFA since the observed red fruit has been left (brooded) at room temperature for 2 days. Ngando et al. (2013) reported that the lipase was activated on the fruit palm when ripe or bruised and injured and caused triglyceride hydrolysis and produced FFA (Figure 2). In addition, Santoso et al. (2011) explained that during the maturation process, the red fruit grains that are embedded in the pith will be more stretchable, more easily separated, with a soft pulp texture, resulting in easy bruising due to physical injury. Santoso et al. (2011) also reported that during the fruit ripening process in the tree, the leaf sheath will dry out, thus no longer providing protection against red fruits and susceptible to chemical damage such as hydrolysis and oxidation. It was also reported that the FFA levels of extracted red fruit oil varied in each clone because it had different lipase activity in triggering the hydrolysis reaction as well as having different fruit maturity levels (Sarungallo et al., 2016).

\subsection{Effect of heat treatment on carotenoids and tocopherols content}

The total content of carotenoids and tocopherols of red fruit oil before heating (control) decreasing with the heating treatment (Table 2), was directly proportional to the rise in temperature and heating time and showed a significant difference $(\mathrm{P}<0.05)$ between treatments. The highest carotenoid content of RFO was demonstrated by treatment without heating (control), tending to decrease with a temperature increase of $100^{\circ} \mathrm{C}$ (5-45 mins) of $17.8 \%, 20.9 \%$ at $110^{\circ} \mathrm{C}(5-30 \mathrm{mins})$, and $20.7 \%$ at $120^{\circ} \mathrm{C}$ (3-20 mins). While decreasing of total tocopherol content by heating at $100-120^{\circ} \mathrm{C}$ is relatively low at around 9$10 \%$. These results indicate that tocopherols of RFO are relatively more resistant to heating than carotenoids. Karabulut (2010) reported that $\alpha$-tocopherols the most active antioxidant compare to $\beta$-carotene and ascorbyl palmitate in triacylglycerol oxidation studies. Further, Zeb and Murkovic (2011) also reported that $\beta$-carotene in corn oil degraded prior to the oxidation of triglycerides. The same phenomenon was also reported in the process of extracting palm oil with sterilization for 
0-40 mins to improve the oil yield, but also increase the loss of $\beta$-carotene (Fauzi and Sarmidi, 2010a) and $\alpha$ tocopherol (Fauzi and Sarmidi, 2010b). It was further explained that the degradation of $\alpha$-tocopherol tends to decrease during storage of palm oil (Fauzi and Sarmidi, 2010b), which could be caused by the synergistic effect of $\beta$-carotene as an antioxidant component which also found in palm oil (Chandrasekaram et al., 2009). It was also explained that the active components (carotenoids and tocopherols) were very sensitive to oxygen, light, temperature and acidity because they have multiple conjugated bonding structures that contain many reactive and oxidizing electrons (Wilska-Jeszka, 2006). However, the presence of tocopherols and $\beta$-carotene together showed a protective effect against the oxidative stability of red palm oil (Ayu et al., 2016).

Based on this research, to produce RFO with low FFA content, red fruit should be extracted immediately after harvest, and pay attention to the proper application of heating (autoclave) to inactivate lipase at $120^{\circ} \mathrm{C}$ for 20 mins. Storage of red fruits at room temperature for 2-4 days before extracting the oil was intended to soften tissue and increase oil yield but can increase FFA levels. The increasing of the oil yield can be done by raising the temperature and heating time (autoclave) but the content of carotenoids and tocopherols will decrease.

\section{Conclusion}

Heating treatment prior to extraction increased the oil yield but decreased total carotenoids and total tocopherols content of the resulted oil. The heating treatment also tends to increase the FFA content of red fruit oil, but the level of increase is decreasing with the increasing of temperature and heating time. Minimum level of FFA content was obtained from sample heated at $120^{\circ} \mathrm{C}$ for 20 mins. The application of red fruit heating at $120^{\circ} \mathrm{C}$ (autoclave) for 20 mins before extraction using hydraulic pressed produced the highest oil yield $(11.5 \pm 0.3 \%$ of total extracted grain) with total carotenoids $(6148 \pm 65 \mathrm{ppm})$, total tocopherols $(1515 \pm 24$ ppm), and FFA levels $0.76 \pm 0.1 \%$, without significant differences $(\mathrm{P}<0.05)$ with control samples (i.e., samples without heating treatment) $0.71 \pm 0.2 \%$. To further reduce the FFA content, it is recommended to study the effects of heat treatment of red fruit immediately after harvest.

\section{Conflict of Interest}

The authors declare no conflict of interest.

\section{References}

AOCS (American Oil Chemists' Society). (2017). Official Methods and Recommended Practices of the
AOCS. $7^{\text {th }}$ ed. Methods Ca 5a-40. Champaign, IL, USA: AOCS.

Anderson, D. (2005). A Primer on Oils Processing Technology. In F. Shahidi (ed). Edible Oil and Fat Products: Processing Technologies. Bailey's Industrial Oil and Fat Products. Vol. 5, 6th ed., p. 156. New Jersey, USA: John Wiley and Sons, Inc. https://doi.org/10.1002/047167849X.bio077

Ayu, D.F., Andarwulan, N., Hariyadi, P. and Purnomo, E.H. (2016). Effect of Tocopherols, Tocotrienols, $\beta$ Carotene and Chlorophyll on the Photo-oxidative Stability of Red Palm Oil. Food Science and Biotechnology, 25(2), 1-7. https://doi.org/10.1007/ s10068-016-0055-1

Azeman, N.H. Yusof, N.A., Abdullah, J., Yunus, R., Hamidon, M.N. and Hajian R. (2015). Study on the Spectrophotometric Detection of Free Fatty Acids in Palm Oil Utilizing Enzymatic Reactions. Molecules, 20(7), 12328-12340. https://doi.org/10.3390/ molecules200712328

Bhosle, B.M. and Subramanian, R. (2005). New approaches in deacidification of edible oil (a review). Journal of Food Engineering, 69, 481-494. https://doi.org/10.1016/j.jfoodeng.2004.09.003

Chandrasekaram, K., Ng, M.H., Choo, Y.M. and Chuah, C.H. (2009). Effect of Storage Temperature on the Stability of Phytonutrients in Palm Concentrates. American Journal of Applied Science, 6(3), 529-533. https://doi.org/10.3844/ajassp.2009.529.533

Fauzi, N.A.M. and Sarmidi, M.R. (2010a). Extraction of Heat Treated Palm Oil and Their Stability on $\beta$ carotene During Storage. Journal of Science and Technology, 2, 45-54.

Fauzi, N.A.M. and Sarmidi, M.R. (2010b). Extraction of Heat Treated Palm Oil and Their Stability on $\alpha$ tocopherol During Storage. Journal of Science and Technology, 2, 111-120.

Karabulut, I. (2010). Effects of $\alpha$-tocopherol, $\beta$-carotene and ascorbyl palmitate on oxidative stability of butter oil triacylglycerols. Food Chemistry, 123(3), 622-627.

https://doi.org/10.1016/ j.foodchem.2010.04.080

Kemper, T.G. (2005). Oil Extraction. In: Shahidi, F. (Eds). Edible Oil and Fat Products: Processing Technologies. Bailey's Industrial Oil and Fat Products. Vol. 6, 6th ed., p. 57-98. New Jersey, USA: John Wiley and Sons, Inc. tps:// doi.org/10.1002/047167849X.bio013

Knockaert, G., Lemmens, L., Van-Buggenhout, S., Hendrickx, M. and Van-Loey, A. (2012). Changes in $\beta$-carotene bioaccessibility and concentration during processing of carrot puree. Food Chemistry, 133(1), 60-67.

https://doi.org/10.1016/ 
Li, R., Xia, Q., Tang, M., Zhao, S., Chen, W., Lei, X. and Bai, X. (2012). Chemical composition of Chinese palm fruit and chemical properties of the oil extracts. African Journal of Biotechnology, 11, 93779382. https://doi.org/10.5897/AJB11.3604

Lopes, D.B., Fraga, L.P., Fleuri, L.F. and Macedo, G.A. (2011). Lipase and esterase - to what extent can this classification be applied accurately. Ciencia $e$ Tecnologia de Alimentos, 31, 608-613. https:// doi.org/10.1590/S0101-20612011000300009

Lubis, E.H., Wijaya, H. and Lestari, N. (2012). Study on extraction and stability of total carotenoid, and $\alpha-$ and $\beta$-cryptoxanthin of red fruit (Pandanus conoideus Lamk) extracts (in Indonesian). Jurnal Riset Teknologi Indonesia, 6, 126-140.

Matthaus, B. (2012). Oil Technology. In Gupta, S.K. (Ed). Technological Innovations in Major World Oil Crops: Perspectives. Vol. 2, $1^{\text {st }}$ ed. p. 23-92. Berlin, Heidelberg, Germany: Springer-Verlag. https:// doi.org/10.1007/978-1-4614-0827-7_2

Murtiningrum, Sarungallo, Z.L. and Mawikere, N.L. (2012). The exploration and diversity of red fruit (Pandanus conoideus L.) from Papua based on its physical characteristics and chemical composition. Journal of Biodiversity, 13(3), 124-129. https:// doi.org/10.13057/biodiv/d130304

Ngando, E.G.F, Mpondo-Mpondo, E.A. and Ewane, M.A. (2013). Some quality parameters of crude palm oil from major markets of Douala, Cameroon. African Journal of Food Science, 7, 473-478. https:// doi.org/10.5897/AJFS2013.1014

Ngando, E.G.F., Dhouib, R., Carriere, F., Zollo, P.H.A. and Arondel, V. (2006). Assaying lipase activity from oil palm fruit (Elaeis guineensis Jacq.) mesocarp. Plant Physiology and Biochemistry, 44 (10), 611-617. https://doi.org/10.1016/ j.plaphy.2006.09.006

Pahoja, V.M. and Sethar, M.A. (2002). A review of enzimatic properties of lipase in plants, animals and microorganisms. Pakistan Journal of Applied Science, 2(4), 474-484. https://doi.org/10.3923/ jas.2002.474.484

Pohan, H.G. and Wardayani, N.I.A. (2006). Study on extraction process and characterized red fruit (Pandanus conoideus L.) oil. Journal of Agro-based Industry, 23, 26-41 [In Bahasa Indonesia].

Sambanthamurthi, R., Chong, C.L., Khaik, C., Yeu, K.H. and Premavathy, R. (1991). Chilling induced lipid hydrolysis in the oil palm (Elaeisguineensis) mesocarp. Journal of Experimental Botany, 42(9), 1199-1205. https://doi.org/10.1093/jxb/42.9.1199

Santoso, B., Murtiningrum and Sarungallo, Z.L. (2011). Morphological Fruit during Development Stages of
Red Fruit (Pandanus conoideus) (in Indonesian). Journal of Agrotek, 2(6), 23-29.

Sarungallo, Z.L., Hariyadi, P., Andarwulan, N. and Purnomo, E.H. (2015a). Analysis of $\alpha$-cryptoxanthin, $\beta$-cryptoxanthin, $\alpha$-carotene, and $\beta$-carotene of Pandanus conoideus oil by high-performance liquid chromatography (HPLC). Procedia Food Science, 3, 231-243.

j.profoo.2015.01.026

Sarungallo, Z.L., Hariyadi, P., Andarwulan, N. and Purnomo, E.H. (2015b). Characterization of chemical properties, lipid profile, total phenol and tocopherol content of oils extracted from nine clones of red fruit (Pandanus conoideus). Kasetsart Journal (Nature Science), 49, 237-250.

Sarungallo, Z.L., Murtiningrum, Santoso, B. and Roreng, M.K. (2013). The effect of post-harvest handling on red fruit (Pandanus conoideus) oil quality (in Indonesian) presented at Proceedings of the National Seminar of Indonesian Food Technologist Association (PATPI) 26-29 August 2013, p. 150160. Jember: PATPI.

Sarungallo, Z.L., Hariyadi, P., Andarwulan, N. and Purnomo, E.H. (2014). The effect of extraction method on the chemical quality and fatty acid composition of red fruit (Pandanus conoideus) oil (in Indonesian). Jurnal Teknologi Industri Pertanian, 24(3), 209-217.

Sarungallo, Z.L., Murtiningrum, Santoso, B., Roreng, M.K. and Latumahina, R.M.M. (2016). Nutrient content of three clones of red fruit (Pandanus conoideus) during the maturity development. International Food Research Journal, 23(2), $1217-$ 1225.

Wilska-Jeszka, J. (2006). Food Colorants. In Sikorski, Z.E. (Ed). Chemical and Functional Properties of Food Components. $3^{\text {rd }}$ ed. New York, USA: CRC Press. https://doi.org/10.1201/9781420009613.ch9

Wong, M. L., Timms, R.E. and Goh, E.M. (1988). Colorimetric determination of total tocopherols in palm olein and stearin. Journal of the American Oil Chemists' Society, 65(2), 258-261. https:// doi.org/10.1007/BF02636412

You, L.L. and Baharin, B.S. (2006). Effects of enzymatic hydrolysis on crude palm olein by lipase from Candida rugosa. Journal of Food Lipids, 13(1), 7387. 4522.2006.00035.x

https://doi.org/10.1111/j.1745-

Zeb, A. and Murkovic, M. (2011). Determination of thermal oxidation and oxidation products of $\beta$ carotene in cornoil triacylglycerols. Food Research International, 50(2), 534-544. https:// doi.org/10.1016/j.foodres.2011.02.039 